RESEARCH ARTICLE

\title{
Biopolitics of Non-Motherhood: Childfree Women on a Persian-Language Digital Platform for Mothers
}

\section{Ladan Rahbari'}

\begin{abstract}
In Iran, motherhood continues to be considered an important and essential part of women's social life. However, nonmotherhood is gaining momentum as Iranian women increasingly choose to be childfree. This study explores women's perceptions of motherhood using the content of a Persian-language discussion and mini-blogging forum called Ninisite. Ninisite is one of the largest interactive digital spaces dedicated to topics such as family, motherhood, fertility, infertility, pregnancy, childbirth, and childcare. This study uses a combination of cyber-ethnography and critical discourse analysis to investigate users' attitudes and perceptions on non-motherhood and childfreeness on Ninisite. The research shows the participatory and solidarizing climate on Ninisite's interactive blogosphere to provide informative, spiritual, and affective support, not only to mothers but also to non-mothers in a context where childfreeness is stigmatized as well as socially and politically scrutinized. Keywords: Biopolitics $\bullet$ Childfree $\bullet$ Digital $\bullet$ Motherhood $\bullet$ Religion $\bullet$ Solidarity $\bullet$ Women
\end{abstract}


Motherhood is a position of social and political struggle for women in Iran. On the one hand, the Iranian State's pronatalist biopolitics have actively played into traditionalist concepts of femininity that entail a naturalized and normative notion of maternity, while on the other, motherhood continues to be a socially and culturally valued role for women. However, despite the State's and policymakers' efforts, birth rates have been gradually dropping, and the country's young population is more reluctant than ever to procreate. This has alarmed the country's political conservatives (Deutsche, 2020). In a defining moment, Iran's Supreme Leader Ayatollah Ali Khamenei gave a speech in 2012 criticizing Iran's previous population control policies (Erfani, 2017) that had successfully curbed the population increase after the 1990s. The familyplanning policies that aimed for population control and reduction of birthrates were enacted with involvement and endorsement from the country's religious leaders, such as Ayatollah Khomeini (Hoodfar, 2008). The new approach was a turning point in the official approaches on addressing family planning, population management, and biopolitics in Iran. Following the supreme leader's assertion, the country curtailed the provision of family planning services and information so as to boost its population.

Apart from the official attitudes toward reproduction and motherhood in Iran, a Shi' ite Muslim majority country, motherhood continues to be considered an important and essential part of women's social lives. The compulsory motherhood discourse is part of the country's mainstream discourses with high normativity and symbolic hegemony. It is enforced and perpetuated by relying on traditional cultural gender norms and using religious and nationalist discourses that emphasize the maternal as the symbolic realm of the nation and the site of its reproduction (Rahbari, Longman, \& Coene, 2019). Despite being stigmatized, non-motherhood has been gaining momentum as many Iranian women increasingly choose to be childfree. A widespread fear is found about an uncertain future among Iranian youth that is coupled with the society being perceived as unstable as well as socially and financially high-risk (Ahmadi, Rafiey, Sajjadi, \& Nosratinejad, 2019). Aside from the weakening traditionalist views on compulsory motherhood, this uncertainty has led to the rise of non-motherhood as a more desired social role for Iranian women. Therefore, the population decline in Iran has gendered explanations, among which are the high costs of fertility for women's social and economic life (Erfani, 2019) in a country where gender inequality is pervasively present and an everyday reality for women.

This study uses cyberethnography and critical discourse analysis to investigate online users' attitudes and perceptions toward non-motherhood and being childfree/ childless on Ninisite (www.ninisite.com), the Persian language discussion and miniblogging forum. The website's name is a combination of the Persian word nini (meaning infant) and site (the abbreviated form of website). Ninisite is one of the largest interactive digital spaces in Persian dedicated to offering a platform to users for 
discussing issues such as family, motherhood, fertility, infertility, pregnancy, childbirth, and childcare. The website's tagline introduces it as a guide for pregnancy and childcare. It is thus a space predominantly - if not specifically - designed for advice on maternity and childbearing as well as their surrounding discourses. The website combines advisory pieces and guidelines produced by specialists and open forums for registered users to interact with each other. Ninisite enjoys great popularity in Iran. While it does not explicitly aim to attract women, it is predominantly frequented by women who seek information, support, or advice on an array of family-oriented issues, among which pregnancy, fertility, infertility, and motherhood remain very central themes. Despite this obvious orientation toward motherhood, a growing number of mini-blogs and open discussions regarding voluntarily non-motherhood and child-freeness are found to have begun appearing on Ninisite.

This study will explore users' attitudes and perceptions on non-motherhood and being childfree on Ninisite. The central question the research engages with is exploratory and primarily investigates the user-created discourses on non-motherhood in the digital environment of Ninisite. The study aims to inquire into whether or not and how far these discourses perpetuate, resist, or deconstruct the gendered biopolitics promoted by the Iranian State and conservative clergy. The participatory nature of Ninisite and its stated orientation toward advice to parents and those seeking parenthood make studying non-motherhood a specifically interesting case to study. The study is organized as follows: The first section will provide a general overview of social and political perspectives on non-motherhood in Iran. The next section will describe Ninisite's environment and locate it within the digital Iranian and Persian-language blogospheres. The paper will then identify the research methods before analyzing the findings. The final section is dedicated to a more in-depth discussion on Iranian women's digital discourses around non-motherhood and childfreeness on Ninisite.

\section{Politics of Non-Motherhood in Iran: A Brief Overview}

Former Iranian President Mahmoud Ahmadinejad (in office between 2005 and 2013) was the one who first highlighted the need for increasing the country's population, stating that Iran could support a population of up to 150 million people (Iran's population was around 75 million at the time). He further declared the long-standing family planning strategy of the country, which had focused on two children per family, to have stemmed from a wrong and imported Western perspective (Karamouzian, Sharifi, \& Haghdoost, 2014). This standpoint was later supported and endorsed by the country's supreme leader Ayatollah Khamenei, who insisted that population increase and having more populated families would be possible by "promoting and establishing an Islamic Iranian lifestyle and confronting the negative aspects of the Western lifestyle," among other strategies (Khamenei, 2014). 
After Ayatollah Khamenei adopted this stance, the Iranian State biopolitics shifted strategies of family planning dramatically. The swift shift meant that the State targeted the national family planning program, discontinued all birth control education programs, and limited permanent sterilization methods. The Iranian Parliament followed suit and backed a pronatalist bill that outlined various incentives for childbearing, including early retirement for mothers, tax relief, and child benefits for large families, as well as punishments for unauthorized birth control providers (Rahbari et al., 2019). While other studies have shown both marriage and fertility decline to be a reality and to have created significant policy challenges for the country (Hosseini-Chavoshi, AbbasiShavazi, \& McDonald, 2016), others have argued the Iranian State's approach to tackling these challenges to hurt women and to have put them in a more vulnerable social and economic position than before. In this paper, I do not intend to address Iran's demographic change or examine whether the new population strategies are demographically viable; instead, I intend to trace the possible effects the changes in policy, rhetoric, and political discourse have had on childfree women. With social and financial benefits mostly allocated to families and mothers, childfree non-mothers have specifically been left out of government support programs. With the prohibition of information campaigns, the reduction of access to both temporary and permanent contraceptive methods, and the unavailability of safe abortions, women who aspire to stay childfree have become the epitome of an anomaly.

The Iranian society is not homogeneous and has diverse attitudes toward voluntary non-motherhood (childfreeness) that vary dramatically based on many factors such as but not limited to religiosity, education, socio-economic background, and rural-urban settings. Motherhood is traditionally valued, especially among the majority of the country's Shi' ite population, who adhere to the Twelver Shi'a branch of Islam (Rahbari, 2020b). Overall, non-motherhood could be considered a less-privileged position in both society and politics. The topics of family planning and non-motherhood, however, have become even more politicized after these changes in the state's policy approaches and open endorsement by Iran's top politicians. The excessive politicization of family planning is highly gendered, as women have been the most highly affected by the policy implications from the shift in family planning.

Non-motherhood in Iran is also entangled with other social stigmas and taboos, such as singlehood (Rahbari, 2016) and infertility (Younesi, Akbari-Zardkhaneh, \& Ardekani, 2006). After the great transformations in Iranian women's education in the past few decades, women have increasingly chosen to stay unmarried and childfree. While tracing a change in the perceptions of Iranians on childfree women is possible, this shift of societal attitudes has neither been documented nor researched. This study's contribution is thus to investigate whether that evidence exists, by exploring the existing perspectives on non-motherhood on a social platform aimed at mothers. I will introduce 
the digital environment and Ninisite's position in Iran's gendered biopolitics in the following section.

\section{Gendered Biopolitics in the Context of Ninisite}

Ninisite is one of the largest digital spaces dedicated to providing platforms for networking, debate, and discussion on issues regarding family, motherhood, fertility, infertility, pregnancy, childbirth, and childcare in Iran. The website does not share its origin story publicly, but its loyal users speculate that it was founded in 2006. If this information is correct, Ninisite was launched only two years after the social media platform Facebook and in the same year as Twitter (Lupton, 2014). The website released a statement in 2017 about its number of users and visitors: 33 million visitors per day and 10,000 new user accounts per month. Ninisite presents itself as an educational and informative platform but warns users that it is only oriented toward lifestyles, not health or expert advice. The platform is thus saturated with how-to content on mothering.

Ninisite strives to stay as apolitical as possible. Users and platforms such as Ninisite tend to actively present themselves under the mantles of lifestyle and health partly because of the severe repercussions that explicit political activity or expressions would have in digital spaces. Most expert advice on Ninisite tends to address popular approaches to health and fertility, and avoiding topics that might be perceived as controversial or not in alignment with government policies is a clear trend. While Iran's cyber-police monitors the nationally accessible Internet regularly and systematically curbs access to political and critical voices, Ninisite's place within the Iranian digital platforms and blogosphere on lifestyle is a relatively safe one. This is not only because of Ninisite's engagements with topics that are considered non-sensitive and non-controversial but also because of the platform's conscious attempts and content-deletion strategy to stay as far away as possible from politics.

Ninisite's communication and community guidelines strictly ban all "immoral" and socially unacceptable content in general and politically motivated and sexual content in particular. Even despite these attempts, the platform found itself in the middle of a media dispute sparked by the more conservative media platforms that accuse Ninisite of leniency toward the non-Islamic and immoral content published on their platforms (Mashreghnews, 2020). Ninisite reacted with a statement release explaining that Ninisite not only complies with the policies and laws of the Islamic Republic of Iran and Islam, and their rules, but it also has not overlooked the promotion of Iranian Islamic culture (Tabnak, 2017). The emphasis on the elements of Iranian and Islamic are an indication of Ninisite's attempt to appeal to the State's national political agenda characterizing these two notions (Rahbari et al., 2019). 
Ninisite forums are interactive and, while predominantly frequented by women, are open to everyone. Men's relatively smaller levels of contribution to Ninisite's blogosphere, on which parenting and childcare advice is sought for and provided, is partly an indication of the gendered division of labor that leaves women the responsibility for childcare and other care activities (Torabi, 2020). Women often seek information, support, or advice on many areas of family-oriented issues on Ninisite, on which motherhood stays the central theme. Besides these dominant forms, however, miniblogs have become more frequent, and open discussions regarding infertility, nonmotherhood, and childfree-/childless-ness have appeared on Ninisite. The platform offers the space to start a conversation on a certain topic. Two roles are foreseen for those participating in a topic. Starter is the role of the person who starts a conversation by asking a question or mentioning an important issue to motivate a discussion. Discussants are all the other participants who react to the starter's initial post. As the discussions predominantly take place textually, the possibility remains that the debate will not stay on topic. In my analysis of the discussions on Ninisite, I will adopt these terms to refer to different participant roles on the platforms.

While Ninisite's efforts to reduce political content have been an effective strategy to some extent, the possibility has always been present for leaks such as political messages making their way to the public sphere through implicit forms of political expression. As discussed by Rahbari (2020a), the seemingly apolitical approach adopted in online spaces could be interpretd as a political strategy of survival. My cyberethnographic research into Ninisite has shown examples of politically charged comments on women's rights, the State's problematic biopolitical approaches to reproduction, and expressions of political dissent to have leaked and been present within conversations, with topics ranging from breastfeeding to children's yoga. However, these leaks are actively eliminated from the website by the admins. Reports are also found of user accounts being deactivated because of non-compliance with Niniste's rules of conduct regarding making political comments.

\section{Methods}

This study uses a combination of cyber-ethnography and discourse analysis to investigate the attitudes and perceptions of Ninisite's participants on non-motherhood and being childfree/childless. The website's interactive forums, content, interactions, and mini-blogs have been explored within the purpose of this research. To clarify the terminology users apply on Ninisite forums, a topic is used to refer to the mini-blog a starter creates. The topic will appear on top of the page, and other users can interact with it by reading or reacting to it visually and textually. Every topic has reports on the number of reads and posts. The number of reads refers to all the people who have opened and viewed the blog post the starter posted. The number of posts refers to other users' 
responses in the form of small blog posts responding to the topic and appear under the main discussion. The data for this paper were gathered through the cyber-ethnographic research on Ninisite as well as a systematic thematic search on the platform using Persian search terms such as bifarzandi [child-freeness], nini/bacche nakhastan, bacche nemikham [voluntary childfreeness], and madari/madar nakhastan [not wanting to become a mother] between November 2019 and April 2020. The initial research showed the topic of childfreeness to prove to have a clear minority position among the shared topics; however, 20 entries were found addressing childfreeness that were shortlisted for further analysis. These 20 topics were then further narrowed down to six based on the number of responses and posts they received. Topics without posts or with less than 20 posts were excluded from the analysis as they had not created enough engagement from the users. The study thus consisted of data gathered from six topics: Topic 1 (Is not wanting children a sin? 812 reads and 92 posts). Topic 2 (I don't ever want to have children, 5,422 reads, 44 posts). Topic 3 (So what if I don't want children? 822 reads, 44 posts). Topic 4 (After joining this website, I learned I do not want children. 1,593 reads, 70 posts). Topic 5 (I don't want children at all, 2,750 reads, 111 posts). Topic 6 (I do not want the child that I am carrying, 1,996 reads, 197 posts).

Ninisite is not a networking platform and thus differs from social media, especially in that the platform is predominantly designed for allowing conversations and questionsand-answers without the burden of making personal profiles rather than social networking. This approach has specifically resulted in attracting users who value anonymity. Most users on the platform use fake account names and do not share information that would facilitate identifying them. After gathering the data consisting of textual and visual (mostly emoji) content, the analysis was conducted using Critical Discourse Analysis (CDA). Critical discourse analysis reveals the relations of power and dominance in discourses as well as how social forces are reproduced or contested using linguistic and discursive strategies (Van Dijk, 1993). The analysis was first conducted by finding nodal points and themes on linguistic and non-linguistic levels through which the centralized and privileged concepts within the discourse were identified (Erdogan, 2016). The lexical choices were generally explored, as were the argumentations and lexical choices in relation to motherhood and childfreeness. The discourse analysis process consisted of critical reading and rereading the links and positioning the texts in the social and digital context (Leitch \& Palmer, 2010) within the media (KhosraviNik, 2017), which in this case is Ninisite.

It is important to add that the researcher's familiarity with the Persian language (as a native speaker) and her position as an Iranian woman facilitated her participation in the digital platform. Selected posts were translated from Persian to English by the author. Some quotations were selected and translated to illustrate the findings and enrich the text. Because Persian is a genderless language and does not contain gender- 
exclusive grammatical or lexical structures compared to gender-specific languages, special attention was given to the precision of gendered translation outcomes.

\section{Findings}

\section{Childfreeness on Ninisite}

Four topics are included in the data that are engaged directly with voluntary and agentic rejection of motherhood: Topic 1 (Is it a sin not to want children? 812 reads and 92 posts), Topic 2 (I don't ever want to have children, 5,422 reads, 44 posts), Topic 3 (So what if I don't want children? 822 reads, 44 posts), and Topic 5 (I do not want children at all, 2,750 reads, 111 posts). The starter text for topic one is as follows:

I have been married for two and a halfyears, and I really do not like [the idea of having] children, and my husband does not either. I am 27 years old, and [we] really do not have any intention to have children. Our financial situation is not bad-although we have been under lots of pressure for some time - but in general, [our financial situation] is not bad, but we just do not want children. Now, our relatives are putting us under pressure. I mean, it is impossible that we go somewhere and [people] do not bring up that we should have children. For this, I do not like to go anywhere at all, and the more they say it, the more I do not like [the idea of having] children. I am so tired. This is my life. I do not want children. Why do people behave as if I am committing a grave sin because I do not want to have children? (Starter, Topic 1)

This topic exemplifies the frustration women have who choose childfreeness when they encounter compulsory, motherhood societal attitudes. The repetition of "do not want" in Topic 1 indicates the emphasis put on the voluntary nature of childfreeness. Several comments were made in response to this post that showed solidarity with the starter. While most of these comments were from users who themselves had experienced similar forms of social stigmatization and pressure to have children, mothers also reacted to the topic, sometimes in solidarity. Some discussants shared their own stories and frustration and encouraged the starter to ignore the pressure:

Do not pay attention to them. I do not want children either. It is only a group of uncultured people who say [such things]. I was once even forced to say, "I hate children, do not keep mentioning it to me." (Discussant, Topic 1)

Another user questioned the presumption of the idea of non-motherhood as a sin and critiqued the way this assumption depicts God, saying, "Only the grumblers who think God is evil... [would think it is a sin not to have children]" (Discussant, Topic 1). Another participant suggested, "Tell them your husband is the one who does not like [the idea of having] children" (Discussant, Topic 1). While this latter comment, on the one hand, implies that women are under more pressure to have children, it also connotes that it is more socially acceptable for men not to want to have children and that men's decisions on parenthood are considered more valid and justified. Some 
discussants used the opportunity to critique society's fixation on other stereotypical roles for women:

These [nagging] people are like this; when you are single, they ask when you will get married; when you do the nikah [Islamic marriage], they ask you when the ceremony is; when you have your ceremony, they ask when you will have children. They will just interfere in your life until your death. (Discussant, Topic 1)

One participant humorously pointed out that women without children not only feel the pressure to have children but also endure inappropriate comments that reveal gender bias and son preference:

If you have a child, then they will comment on [the child's] gender... They will tell you that you should have a boy first. As if children are ready-made, and I can simply go and pick one out somewhere. (Discussant, Topic 1)

Other discussants, some of whom were mothers, suggested alternative motherhood. This group of comments assumed pregnancy itself to be what is undesired, advising non-mothers not to miss out on motherhood by considering adoption. In this line, one discussant suggested:

[If you do not want to have a child and your husband insists] then adopt a child. It is a rewarded, altruistic act with savaab [deeds that have a spiritual reward in Islamic ethics] and does not contribute to the overpopulation [of the planet]. You will change a human being's life forever. (Discussant, Topic 3)

The supportive and solidarizing environment of the platform was revealed in Topic 4 (After joining this website. I learned I do not want children, 1,593 reads, 70 posts). In this topic, the starter explained that attending Ninisite and reading about other women's experiences revealed to her that she had made the right choice not to have children. This starter also distinguished between childfree and childless women and invited everyone not to ask questions about women's reproductive choices because one can never know whether a woman is voluntarily childfree. This comment indicated that, while childlessness and fertility issues are considered taboo and sensitive topics, childfreeness as a voluntarily chosen position is not. This topic sparked interactions and messages of support and solidarity among childless women who aspired motherhood and struggled with fertility as well as childfree women who expressed frustration over their stigmatized position in society. The women within the two groups bonded over their shared experience of stigmatization and othering as well as the shared interest in de-problematizing women's non-mainstream reproductive choices.

\section{Discourses on Compulsory Motherhood}

While the general environment of Ninisite is supportive of non-mothers who declared their preference for childfreeness, the starters were sometimes asked to explain how 
their choice of childfreeness had affected people around them, especially their husbands. For example, Topic 6's starter was asked to clarify whether she had always not wanted children and if she had made her choice clear to her husband from the very beginning of their relationship. The starter was compelled to explain herself:

Last night I wrote that I never want to have children, but my husband says, "Let us just wait until you want them "... Many of you told me that I should have told him during khastergari [the Persian proposal ceremony]. [To be clear] I did inform him during dating as well as in khastegari. (Starter, Topic 6)

In other instances, the starters were also warned by some discussants that not having children can have consequences for the couple and might affect the spousal relationship:

Why do you not want children? How long do you think a couple's life stays sweet [without children]? Everything becomes repetitive after a while. (Discussant, Topic 3)

Other comments similarly showed strong advocation for the husband's right and preference to have children, sometimes giving more priority over the wife's choice. In some topics, women were asked if their husbands agreed with them, and if not, they were invited to compromise for the sake of their "family." Family as a word is predominantly used to refer to couples who have children. A wife's choice to not have children when the husband really wants children was considered unfair: "You cannot just reject children if your husband wants them," said a discussant firmly (Topic 2).

Women were sometimes called selfish for not wanting children. One starter who shared that she did not wish to have children despite her husband's will was called selfish and received comments such as, "I wish God will not grant you children even if you want them," (Discussant, Topic 5). However, responses of this type were in the minority, as most discussants offered different advice and strategies to the starter, from talking to the husband about the issue and getting counseling to playing safe and not talking about the issue. Divorce as a result of the couple's different aspirations was very rarely discussed in the topics I studied. In five topics, only one comment (in Topic 3) suggested: "choosing a different path from that of her husband" to perhaps be the best solution for the starter, who did not want children. The reluctance to even use the term "divorce" reflects the general taboo on the dissolution of marriage in the context of Iran, where it is specifically stigmatized for women.

In Topic 6 (I do not want the child that I am carrying, 1,996 reads, 197 posts), the starter discussed that, besides not wanting to have children, she was also unhappy to hear that her child was going to be "a girl." She explained that she did not have gender bias, but because of her own experience as a woman, she did not consider the sexist social environment suitable for raising a daughter. This topic was the most controversial and received mixed reactions. One discussant reproached the starter and asked her to 
work on her "mindset and personality." The starter was called "ungrateful" for not wanting the "gift of God" and was invited to change her attitude. Topic 6 was contested relatively more by discussants because the starter was already pregnant. While there was no mention of an intention to terminate the pregnancy, the fact the mother was unhappy with being pregnant with a child was considered deeply problematic. ${ }^{1}$

\section{Non-Motherhood and Motherhood Beyond Mothers}

My observations on Ninisite showed religious beliefs to play diverse roles in the experiences of both mothers and non-mothers. When discussing societal attitudes toward non-motherhood and motherhood, religious references were made by starters and discussants alike to contest compulsory motherhood. Religion was thus a source of support for mothers and non-mothers alike. However, some discussants warned non-mothers of their arrogance toward God by not wanting children. This view, which interpreted childfreeness as a sign of ingratitude, stated that children were gifts of God, and those who could have children should not abstain from it because so many women struggle with fertility. Accepting or rejecting children is not up to the individual:

Dear... just see what your ghesmat [fate] is. There are so many who do not want children, but God has granted them. If God gifts them to you, then be thankful. (Discussant, Topic 3)

Faith is not the only thing to provide spiritual support. Prayers are considered effective for having one's reproductive wishes granted. Various prayers were suggested to women who struggle with fertility. In Topic 6, the starter explained that she wanted to have a boy, and she was pregnant with a girl despite her efforts and prayers:

A woman who has three boys told me to recite a specific prayer from Mafatih al-Janan [a Shi'i Islamic compilation book of narratives and prayers] for having sons. Whoever has recited it has definitely had boys. I recited it so many times, and it was useless. (Strater, Topic 6)

While having a gender preference pre-pregnancy was not seen as problematic, expressing a gender preference after pregnancy was not an accepted or welcome discussion in the forum; many negative reactions were found toward this post-pregnancy preference because of the indication that the mother is not respecting God's will. When this starter expressed regret for the gender of her child, she was told to:

Pray that despite your ungratefulness, God will grant you a healthy child. Otherwise, you will have a curse upon yourself for a lifetime. (Discussant, Topic 6)

Another recurring theme apart from religion was childfreeness being a result of Iran's political instability. The politically motivated arguments attempted to build the case against having children in Iran because of adverse socio-political situations. These

1 Termination of pregnancy is taboo in Iran, and despite the partial legalization of 'medical abortions' in the case of pre-existing fetal and maternal conditions (Mahdavi, Jafari, Azimi, Dehghanizadeh, \& Barzegar, 2020), it remains a highly controversial practice. 
comments often critiqued Iranian politics and the condition of the country's economy and human rights:

For the love of God, please do not have children in this country where no one's fate is clear. God is my witness that my husband says the same thing... in this country where [the child] would become more and more depressed and will be deprived of their most basic rights. (Discussant, topic one)

Discussants in other topics expressed similar opinions, stating that having children in Iran was 'cruelty' against the unborn child and not the right thing to do 'under current circumstances in this country.' While the discussions did not attempt to go deeper into providing explanations on the social and political conditions that made having children undesirable for the discussants, the general consensus was that this is the case. Considering that political discussions on Ninisite are strictly forbidden, and user accounts can be deactivated in case of non-compliance, these tacit forms of social and political critique are some of the strategies Iranian users employ to avoid possible repercussions. None of the posts criticizing Iran's political situation received negative replies or backlash, nor did they create substantial argumentation.

\section{Discussion}

This study used a combination of cyber-ethnography and discourse analysis to investigate users' attitudes and perceptions toward non-motherhood and childfreeness on Ninisite, a lifestyle, advice, and interactive blogging forum. The central question the study engaged with was exploratory and investigated the user-created discourses on non-motherhood in the digital environment of Ninisite. The study aimed to (i) inquire whether and/or how far the existing user discourses perpetuated, resisted, or deconstructed the gendered biopolitics promoted by the Iranian state and maternalist groups in Iranian society and (ii) to investigate the attitudes and perceptions of users on non-motherhood.

The findings show the overall climate of Ninisite's interactive blogosphere to be participatory and solidarizing and to provide informative, spiritual, and affective support, not only to mothers but also to non-mothers. While Ninisite is not closed to men, it is widely considered a safe space for women to interact with each other. The findings thus show that, even within a context where women's infertility and nonmotherhood are highly stigmatized as well as socially and politically scrutinized, a majority of Ninisite users did not adhere to strict maternalist discourses. The study also revealed that even in digital spaces "officially" dedicated to motherhood, women contest and resist compulsory motherhood. While some user discourses on the platform were maternalist due to how they put excessive focus on and essentialized women's reproduction, maternal health, and child care (Kashani-Sabet, 2011, p. ix), others were 
opposed to compulsory motherhood and considered it a choice that had to be made by the parents.

However, even within the latter discussions that considered motherhood and parenthood a matter of choice rather than a cultural, religious, or social obligation, choice-making was not considered to be an individual act by the non-mother. In fact, quite the opposite, the tendency toward individualistic decision-making that some starters expressed was interpreted as egocentric and unfair to the husband. The starters were invited to repent, to sacrifice their own desires, and to talk to, if not listen to, their husbands. Therefore, while stepping outside of the maternalist and individualist discourses, the notion of couple-centric and sometimes patriarchal parenthood was still observed, as the right to decide not to have children was not reserved for women. The man's right to have a child, albeit sometimes through adoption, was emphasized if not prioritized; women who prioritized their perspectives were told to sacrifice for the family's sake. This form of somewhat divine sacrifice from the woman has been uncovered in other religious groups (see for e.g., Gallagher, Hall, Anderson, \& Del Rosario, 2013; Longman, 2008, p. for Christain and Orthodox Jewish mothers' experiences).

Aside from the comments on personal experiences that showed solidarity and support or sometimes dissent and disagreement with the presented topics, politically motivated comments were also present on Ninisite. These comments criticized Iranian politics and the condition of the country's economy and human rights, which were deemed unsuitable for having children. Childfreeness was thus presented as a conscious political decision that was in the best interest of the parents as well as the unborn child. Sometimes the decision was made despite the discussants' desires to have children. Religion was another theme that was brought up often both to support non-mothers and their choice-making and to make maternalist arguments. Children were considered gifts of God, and women's reproductive decision-making was considered in this light.

Motherhood was not always presented as a merely personal or individual choice. Discussants criticized the grip Iranian society has on women's reproductive decisionmaking and interpreted it as a generally harmful attitude. While many of the topics on Ninisite did not directly engage in social criticism of motherhood as an institution, the topics on non-motherhood did critique the mainstream notions of femininity, family, social responsibility, and religious attitudes, as well as the socio-political and economic context of Iran. These comments showed some of the contextual reasons why women users did not aspire to have children in Iran. Women's choices were embedded within the country's social and economic situation as well as the human rights profile. The discourses showed that women who had chosen to stay childfree did so not only for personal reasons but also because they were very conscious about how their socio- 
political environment would impact their future children. Traditionally impactful discourses such as gender stereotypes and religious beliefs were neither insignificant nor entirely conclusive on women's reproductive decision-making.

Digital activities can include elements of disembodiment and anonymity (Rahbari, 2019) that, in the context of Ninisite, made spaces safe and private for women to discuss otherwise taboo and sensitive topics without revealing their identities. Partly because of the emergence and growth of online spheres (Stalder, 2013) and partial democratization of access to digital media in urban Iran in the past decade, women have gained access to alternative modes, spaces, and networks of support and solidarity. This study thus showed that geographies of solidarity with non-mothers and childfree women are increasingly diversified, and through the everyday usage of digital platforms, even taboo and politically charged topics that go against the State's biopolitics may leak into the Iranian public space.

Peer-review: Externally peer-reviewed.

Conflict of Interest: The author declare no potential conflicts of interest with respect to the research, authorship, and/or publication of this article.

Grant Support: The author received no financial support for the research, authorship, and/or publication of this article.

\section{References}

Ahmadi, S. E., Rafiey, H., Sajjadi, H., \& Nosratinejad, F. (2019). Explanatory model of voluntary childlessness among Iranian couples in Tehran: A grounded theory approach. Iranian Journal of Medical Sciences, 44(6), 449-456. https://doi.org/10.30476/ijms.2019.44964

Deutsche, W. (2020). Iran's declining birth rate alarms country's leaders. Retrieved from https:// www.dw.com/en/iran-birth-rate-decline/a-54371973\#: :text=According\% 20to\%20the \%20 Tehran\%20Times,around $\% 20100 \% 2$ C000\%20births\%20every\%20year.

Erdogan, B. (2016). Humanitarian intervention and the responsibility to protect: Turkish foreign policy discourse. Springer.

Erfani, A. (2017). Curbing publicly-funded family planning services in Iran: Who is affected? Journal of Family Planning and Reproductive Health Care, 43(1), 37-43.

Erfani, A. (2019). Iran's Second demographic transition and belowreplacement fertility: Implications for population policies. İstanbul Üniversitesi Sosyoloji Dergisi, 39(2), 475-478.

Gallagher, J. A., Hall, M. E. L., Anderson, T. L., \& Del Rosario, K. L. M. (2013). A Mixed-methods exploration of christian working mothers' personal strivings. Journal of Psychology and Theology, $41(1), 48-61$.

Hoodfar, H. (2008). Family law and family planning policy in pre-and post-revolutionary Iran (1st ed.). Routledge.

Hosseini-Chavoshi, M., Abbasi-Shavazi, M. J., \& McDonald, P. (2016). Fertility, marriage, and family planning in Iran: Implications for future policy. Population Horizons, 13(1), 31-40.

Karamouzian, M., Sharifi, H., \& Haghdoost, A. A. (2014). Iran's shift in family planning policies: Concerns and challenges. International Journal of Health Policy and Management, 3(5), 231-233. https://doi.org/10.15171/ijhpm.2014.81 
Kashani-Sabet, F. (2011). Conceiving citizens: Women and the politics of motherhood in Iran. Oxford University Press.

Khamenei, S. A. (2014). Ayatollah Ali Khamenei on Iran's population policy. Population and Development Review, 40(3), 573-575.

KhosraviNik, M. (2017). Social media critical discourse studies (SM-CDS). In J. Flowerdew \& J. Richardson (Eds.), Routledge handbook of critical discourse studies (pp. 582-596). Routledge.

Leitch, S., \& Palmer, I. (2010). Analysing texts in context: Current practices and new protocols for critical discourse analysis in organization studies. Journal of Management Studies, 47(6), 1194 1212.

Longman, C. (2008). Sacrificing the career or the family?: Orthodox jewish women between secular work and the sacred home. European Journal of Women's Studies, 15(3), 223-239. doi:10.1177/1350506808091505

Lupton, D. (2014). Digital sociology (1st ed.). Routledge.

Mahdavi, S. A., Jafari, A., Azimi, K., Dehghanizadeh, N., \& Barzegar, A. (2020). Therapeutic abortion in Iran: an epidemiologic study of legal abortion in 2 years. BMC Research Notes, 13(1), 1-6.

Mashreghnews. (2020). Why does the public prosecutor not sue Ninisite?

Rahbari, L. (2016). Sexuality in Iran. In C. L. Shehan (Ed.), The Wiley Blackwell encyclopedia of family studies (pp. 1769-1772). Wiley Blackwell.

Rahbari, L. (2019). In her shoes: Transnational digital solidarity with Muslim women, or the Hijab? Tijdschrift Voor Economische En Sociale Geografie, 112(2), 107-120. https://doi.org/10.1111/ tesg. 12376

Rahbari, L. (2020a). Duffs and puffs: Queer fashion in Iranian cyberspace. Middle East Critique, 29(1), 69-86.

Rahbari. (2020b). Women's Ijtihad and Lady Amin's Islamic ethics on womanhood and motherhood. Religions, 11(2), 88. https://doi.org/10.3390/rel11020088

Rahbari, L., Longman, C., \& Coene, G. (2019). The female body as the bearer of national identity in Iran: a critical discourse analysis of the representation of women's bodies in official online outlets. Gender, Place \& Culture, 26(10), 1417-1437.

Stalder, F., Slater, B. J., \& Iles, A. (2013). Digital solidarity (Post-Media Lab) (Post-Media Lab ed.). Mute.

Tabnak. (2017). Ninisite's reaction to the recent accusations. Retrieved from https://bit.ly/2EbYyIw

Torabi, F. (2020). Spouses' division of household labour in urban areas of Iran. Asian Population Studies, 16(3), 248-263. https://doi.org/10.1080/17441730.2020.1763018

Van Dijk, T. A. (1993). Principles of critical discourse analysis. Discourse \& Society, 4(2), 249-283.

Younesi, S. J., Akbari-Zardkhaneh, S., \& Ardekani, Z. B. (2006). Evaluating stigma among infertile men and women in Iran. Journal of Reproduction \& Infertility, 6(5). 
